\title{
ZARZĄDZANIE W JEDNOSTKACH SAMORZĄDU TERYTORIALNEGO W WARUNKACH SPOLECZNEJ PARTYCYPACJI W REALIZACJI ZADAŃ PUBLICZNYCH
}

\author{
Zbyslaw DOBROWOLSKI* \\ * Instytut Spraw Publicznych, Uniwersytet Jagielloński w Krakowie \\ e-mail: peterdobrowolski@pro.onet.pl
}

Artykuł wpłynął do redakcji 18.05.2013 r., Zweryfikowaną i poprawioną wersję po recenzjach i korekcie otrzymano w listopadzie $2013 \mathrm{r}$.

(C) Zeszyty Naukowe WSOWL

Rezultatami zarzadzania $w$ jednostkach samorzadu terytorialnego powinny być: wysoki standard realizacji zadań publicznych i jednocześnie umacnianie zasad demokracji obywatelskiej. $Z$ perspektywy zarzadzania publicznego $w$ warunkach spolecznej partycypacji w realizacji zadan publicznych istotnego znaczenia nabiera zasada kreowania zaufania publicznego, nie tylko poprzez zapewnienie dostępności i rzetelności, ale także zrozumiatości informacji. Budowaniu zaufania stuży także wspieranie kontroli spotecznej przez jednostki samorządu terytorialnego.

Stowa kluczowe: samorzad terytorialny, partycypacyjne zarzadzanie publiczne, zarzadzanie zaufaniem, kontrola społeczna

\section{WSTĘP}

Refleksję nad problematyką zarządzania jednostkami samorządu terytorialnego w warunkach społecznej partycypacji w realizacji zadań publicznych należy rozpoczać od krótkiego przypomnienia podstawowych ram prawnych funkcjonowania wspólnoty samorządowej, tj. gminy. W myśl przepisu art. 16 ustawy zasadniczej ogół mieszkańców na określonym obszarze stanowi wspólnotę samorządową. Wspólnota ta uczestniczy w sprawowaniu władzy publicznej i wykonuje zadania publiczne w imieniu własnym i na własną odpowiedzialność. Odnotować jednakże należy, iż o ile ustawowe pojęcie jest w pełni zrozumiałe w odniesieniu do gmin i powiatów, o tyle w przypadku województwa samorządowego należałoby mówić raczej o społeczności, gdyż na tym poziomie nie występują już tak silne więzi cechujące wspólnoty. Zaspokajanie zbiorowych potrzeb społecznych należy do zadań własnych gminy. Gminy realizują również określone 21 ustawami zadania zlecone $\mathrm{z}$ zakresu administracji rządowej, a także z zakresu organizacji przygotowań i przeprowadzenia wyborów powszechnych oraz referendów.

Przedstawiciele wspólnot samorządowych, w granicach ustalonych przez ustawodawcę, formułują założenia polityki lokalnej, inicjują i implementują decyzje dotyczące bieżącego funkcjonowania, jak też decyzje o długofalowych i często nieodwracalnych skutkach, na przykład w sprawie zagospodarowania przestrzennego lub sprze- 
daży majątku. Decyzje w sprawie dystrybucji deficytowych dóbr pożądanych przez społeczeństwo podejmowane są w przestrzeni lokalnej, w której ścierają się interesy różnych podmiotów.

Zadania publiczne są realizowane $w$ dobie dzisiejszej nie tylko przez organizacje publiczne, ale także podmioty pozarządowe, w tym w ramach partnerstwa publicznoprywatnego. W takich warunkach prawidłowe wykonanie zadań przez publiczne organizacje samorządowe, obejmujące m.in. gromadzenie zasobów niezbędnych do osiągania celów w zakresie zaspokajania potrzeb zbiorowych, koordynowanie działań z innymi podmiotami, wymaga rozwiązań organizacyjnych umożliwiających dokonanie w odpowiednim czasie niezbędnych korekt, by w lepszym stopniu osiągnąć zakładane cele.

Celem artykułu jest ustalenie zasad zarządzania w jednostkach samorządu terytorialnego w warunkach społecznej partycypacji w realizacji zadań publicznych. Zakres prowadzonych rozważań obejmuje zagadnienia sprawnego funkcjonowania organizacji samorządowych, rozpatrywane z perspektywy nauk o zarządzaniu w obszarze nauk humanistycznych. Artykuł powstał na podstawie studiów literatury przedmiotu, a także wyników badań obcych i własnych.

\section{W KIERUNKU PUBLIC GOVERNANCE}

Odejście od imperatywnego rządzenia i włączenie różnych podmiotów wchodzących w skład otoczenia, w jakim funkcjonuje administracja publiczna w proces inicjowania i realizacji zadań, a także oceny ich efektów jest cechą współczesnego podejścia do funkcjonowania organizacji publicznych, określanego terminem public governance. Zdefiniowanie tego pojęcia w języku polskim napotyka na pewne trudności interpretacyjne wynikające $\mathrm{z}$ różnic językowych, na które zwracają uwagę niektórzy badacze, m.in. A. Nelicki i H. Izdebski. W literaturze przedmiotu public governance definiowane jest jako zadanie zarządzania złożonymi społecznościami poprzez koordynowanie działań podmiotów należących do różnych sektorów (R. Hague, M. Harrop, S. Breslin). Inna z definicji określa public governance jako procesy i instytucje zarówno formalne, jak i nieformalne, które wyznaczają, ale też i ograniczają zbiorową działalność danej grupy. Angażują się w nią, jak zauważają N. Koehane i J. Nye, firmy prywatne, organizacje pozarządowe, nierzadko bez nakazu władzy publicznej ${ }^{1}$. Wyjaśnienia pojęcia public governance poszukuje się poprzez porównanie do koncepcji nowego zarządzania publicznego. O ile w tej drugiej przywiązywano wiele uwagi do mierzenia efektów zarówno indywidualnych, jak i organizacyjnych, o tyle w pierwszej koncepcji zwraca się uwagę na interakcje różnych organizacji. Liczy się nie tylko efekt końcowy podjętych działań, ale także sam sposób działania ${ }^{2}$. Bank Światowy definiuje public governance jako sposób sprawowania władzy w procesie zarządzania zasobami w skali

1 H. Izdebski, Od administracji publicznej do public governance [w:] Zarządzanie publiczne, pod red. J. Hausner, Wydawnictwo Naukowe Scholar, Warszawa 2007, s. 15-16; R. Hague, M. Harrop, S. Breslin, Comparative Government and Politics. An Introduction, Houndmills-Basingstoke, Macmillan 1998, s. 5.

2 T. Bovaird, E. Löffler, Understanding Public Management and Governance [in:] Public Management and Governance, Routledge, edited by T. Bovaird, E. Löffler, London-New York 2003, p. 10. 
makro, którego celem jest rozwój ${ }^{3}$. Z kolei w programie Narodów Zjednoczonych ds. Rozwoju (UNDP) governance jest określane jako sprawowanie władzy w sprawach gospodarczych, politycznych i administracyjnych na wszystkich szczeblach administracyjnych. Obejmuje ono mechanizmy, procesy i instytucje, przez które obywatele i ich grupy mogą artykułować własne interesy, egzekwować prawa i realizować obowiązki, a także mediować kwestiach spornych ${ }^{4}$.

W opracowaniu poświęconym problematyce governance Ministerstwo Rozwoju Regionalnego przytacza definicję Agencji Stanów Zjednoczonych na rzecz Rozwoju Międzynarodowego (United States Agency for International Development - USAID), według której governance to zdolność rządu do efektywnego, wydajnego (tj. oszczędnego) i rozliczalnego procesu zarządzania politykami publicznymi, który jest otwarty na partycypację obywateli i zmierza do wzmocnienia systemu demokratycznego ${ }^{5}$. Przytoczona powyżej definicja nie jest $\mathrm{w}$ pełni poprawna. Zapewne $\mathrm{z}$ powodu niedoskonałego tłumaczenia błędnie przyjęto, iż pojęcie wydajności oznacza oszczędność. Tymczasem z punktu widzenia prakseologii wydajność to maksymalizacja efektów przy danych nakładach, zaś oszczędność to minimalizacja nakładów w celu osiągnięcia efektu.

W przedstawionej powyżej (w sposób skrótowy) próbie konceptualizacji opowiadam się za przyjęciem polskiego odpowiednika public governance - ,,partycypacyjne zarządzanie publiczne", które oddaje istotę koncepcji - rezultaty osiągane są dzięki współpracy, poprzez odpowiednie procedury partycypacyjne, wielu podmiotów - interesariuszy w rozwiązywaniu określonych problemów społecznych ${ }^{6}$. Stosowanie koncepcji good governance przez organizacje publiczne $\mathrm{z}$ jednej strony powinno służyć gospodarnej realizacji zadań. $Z$ drugiej zaś, powinno zapewnić zgodność działania organizacji z uwarunkowaniami prawnymi, sprzyjać kreowaniu zaufania publicznego poprzez stosowanie zasad rozliczalności, przejrzystości, uczciwości. Przyjmuję za J. Chevalierem, B. Spanglerem, E. Freemanem, że interesariuszem (stakeholder) jest każda osoba, która w sposób znaczący wpływa na funkcjonowanie innych osób lub jest dotknięta skutkami decyzji podjętej przez kogoś innego.

\section{ZASADY ZARZĄDZANIA ORGANIZACJAMI PUBLICZNYMI W WA- RUNKACH SPOLECZNEJ PARTYCYPACJI W REALIZACJI ZADAŃ PU- BLICZNYCH}

\subsection{Interaktywne zarządzanie organizacjami publicznymi}

Rosnąca liczba zadań publicznych i ich złożoność wymaga koordynacji działań w celu uzyskania zakładanych rezultatów. Jednocześnie w warunkach zmieniającego się otoczenia i trudności w predykcji tych zmian znaczenia nabiera postulat elastyczności. Modyfikacja działań zbiorowych może następować poprzez imperatywne lub interaktywne podejmowanie decyzji. W tym pierwszym podejściu sposób działania jest określony przez decydentów, a możliwość realizacji zadań przez ich wykonawców znacznie

\footnotetext{
Managing Development. The Governance Dimension, World Bank, Washington D.C. 1991 (maszynopis), s. 15.

4 Koncepcja good governance - refleksje do dyskusji, Ministerstwo Rozwoju Regionalnego, Warszawa 2008 (maszynopis), s. 6.

5 Tamże.

6 H. Izdebski, Od administracji publicznej do public governance, op.cit., s. 16.
} 
ograniczona. Sukces takiego podejścia zależy od trafności przedsięwzięć podejmowanych przez decydentów. Wymaga to dobrego rozpoznania wszelkich uwarunkowań, co wydaje się trudne do osiągnięcia, choćby z uwagi na złożoność współcześnie realizowanych zadań. Inne utrudnienie wynika z faktu, że choć procesie podejmowania decyzji można wyróżnić ostatecznego decydenta, to jednak istnieje szereg podmiotów, które na różnym etapie i w różnym stopniu w nim współuczestniczą, gromadząc, przetwarzając i przekazując przetworzone informacje. Zwrócił na to uwagę H.A. Simon stwierdzając m.in., iż w procesie podejmowania decyzji uczestniczy formalnie lub nieformalnie wiele podmiotów. Wkład podmiotu, który formalnie podjął decyzję, może okazać się niewielki.

W drugim podejściu sukces zależy od wyzwolenia u uczestników życia publicznego zdolności do komunikowania się, interpretowania interesu publicznego i uzgadniania sposobu jego osiągania. Interaktywne podejście do rozwiązywania problemów zarządzania charakteryzuje następujące założenie: organizacje publiczne, a zatem jednostki samorządu terytorialnego, w tym urzędy gmin, starostwa powiatowe, urzędy marszałkowskie oraz pozostałe samorządowe organizacje publiczne, na przykład związki gmin, są ważnymi elementami społeczeństwa i pozostają $\mathrm{w}$ interakcji $\mathrm{z}$ podmiotami tego społeczeństwa poprzez odpowiednie procedury partycypacyjne $\mathrm{z}$ interesariuszami. Podejście to cechuje zaangażowanie interesariuszy, jawność, przejrzystość, równość, brak dyskryminacji w korzystaniu z usług publicznych oraz rozliczalność decydentów ${ }^{7}$.

Przyjmuję implicite, iż chodzi o równe traktowanie przez organizacje publiczne obywateli ze względu m.in. na płeć, przynależność etniczną, wiek, religię itp., na co wskazuje zresztą art. 41 Karty Praw Podstawowych Unii Europejskiej (zbiór fundamentalnych praw człowieka uchwalony i podpisany w dniu 7 grudnia 2000 r. podczas szczytu Rady Europejskiej w Nicei w imieniu trzech organów Unii Europejskiej: Parlamentu, Rady UE oraz Komisji, powtórnie, z pewnymi poprawkami, podpisany przez przewodniczących tych organów podczas szczytu w Lizbonie 12 grudnia 2007 r. Moc wiążąca dokumentu została mu nadana przez Traktat lizboński podpisany 13 grudnia 2007 r., który wszedł w życie 1 grudnia 2009 r.; PL Dziennik Urzędowy Unii Europejskiej C 303/1) stanowiący o prawie obywateli do dobrej administracji, a także art. 32 Konstytucji Rzeczypospolitej Polskiej. Administracja publiczna, złożona z organizacji publicznych, zgodnie z cytowanymi wyżej aktami normatywnymi, jest zobowiązania do przestrzegania $\mathrm{w}$ swoim działaniu zasad: równości, bezstronności, przejrzystości, a także obiektywizmu.

O ile ostatnie trzy zasady są w pełni zrozumiałe, doprecyzowania wymaga zasada równości. Pojęcie równości nie oznacza jednakowych obowiązków administracji publicznej i interesariuszy w inicjowaniu i realizowaniu zadań publicznych. Akty normatywne różnicują bowiem zadania i odpowiedzialność za wykonywanie zadań publicznych. Organizacje publiczne są zobligowane do realizacji takich zadań na zasadzie powszechności. Działania innych interesariuszy, na przykład organizacji pozarządowych, mogą być adresowane do konkretnych grup społecznych i nie są obligatoryjne.

J. Hausner, W kierunku rządzenia interaktywnego [w:] Nowe zarzadzanie publiczne $i$ public governance $w$ Polsce $i$ w Europie, pod red. A. Bosiacki, H. Izdebski, A. Nelicki, I. Zachariasz, Liber, Warszawa 2010, s. 93-94. 
Z perspektywy interaktywnego podejścia do rozwiązywania problemów zarządzania, na organizacjach publicznych (tj. takich, które zostały stworzone wyłącznie w celu realizacji interesu publicznego) spoczywa obowiązek wspierania działalności interesariuszy w zakresie realizacji zadań publicznych, a także kontroli i oceny realizacji tych zadań.

Zasada równości oznacza jednakowe traktowanie przez administrację publiczną obywateli, załatwianie spraw według jednolitych, obiektywnych kryteriów. Oznacza także możliwość przedstawienia przez interesariuszy swoich opinii, argumentów oraz zapoznania się ze stanowiskiem innych podmiotów biorących udział w procesie decyzyjnym, a także dokonania ocen działalności administracji publicznej. Służy temu dyskurs społeczny.

Jest on niezbędny dla zapewnienia jawności i przejrzystości działania administracji publicznej, rozliczalności decydentów, zaangażowania interesariuszy w realizację zadań publicznych. Pozwala nie tylko na lepsze rozpoznanie społecznych potrzeb, ale także na uniknięcie potencjalnych konfliktów społecznych. Dla organizacji publicznych dyskurs społeczny stwarza możliwość uzyskania społecznej akceptacji dla planowanych działań. Decyzja, która zostanie podjęta nie musi reprezentować woli wszystkich. Musi stanowić rezultat dyskusji, w której wszyscy mogą brać udział. Powyższa konstatacja jest zbieżna $\mathrm{z}$ założeniem teorii legitymizacji prawa sformułowanej przez J. Habermasa.

\subsection{Warunki zaangażowania społecznego}

Warunkiem sine qua non prawidłowego dyskursu społecznego jest dostępna i rzetelna informacja. Za zapewnienie rzetelności informacji odpowiedzialne są m.in. samorządowe organizacje publiczne (m.in. urzędy gmin, starostwa powiatowe, urzędy marszałkowskie), a sposób jej przekazywania jest określony w ustawie z dnia 6 września 2001 r. o dostępie do informacji publicznej ${ }^{8}$. Akt normatywny stanowi zatem formalną podstawę sprzyjającą dyskursowi społecznemu. Odnotować jednakże należy, iż podstawą skutecznego skorzystania przez interesariuszy z prawa do informacji o sprawach publicznych i aktywnego uczestnictwa w dyskursie społecznym jest nie tylko zapewnienie, aby informacja była dostępna i rzetelna, ale także, aby była zrozumiała. Powyższą konstatację potwierdzają rezultaty badań przeprowadzonych przez A.P. Wiatraka poświęcone m.in. problematyce uspołecznienia przygotowania strategii rozwoju gmin wiejskich. Badania wykazały, iż brak dostatecznego udziału lokalnych społeczności w przygotowaniu strategii rozwoju gmin wiejskich powoduje, że nie odpowiadają one oczekiwaniom tych społeczności. Brak zaangażowania mieszkańców gmin w proces tworzenia strategii wynikał m.in. $\mathrm{z}$ niepełnego zrozumienia zakresu proponowanych konsultacji. Użyte słownictwo było niedostosowane do poziomu ich wykształcenia. Lokalna społeczność nie miała dostatecznych informacji o wynikach konsultacji i podjętych decyzjach, a w szczególności o kryteriach, jakimi kierowano się przy podejmowaniu decyzji ${ }^{9}$.

Wyniki badań pozwalają na sformułowanie teoretycznych uogólnień, iż zdolność zrozumienia informacji przez adresata powinna być oceniana przez samorządowe

\footnotetext{
Dz. U. Nr 112, poz. 1198, ze zm.

9 A.P. Wiatrak, Strategie rozwoju gmin wiejskich, Instytut Rozwoju Wsi i Rolnictwa PAN, Warszawa 2011, s. 152.
} 
organizacje publiczne i stanowić asumpt do podjęcia odpowiednich działań w celu lepszego przygotowania obywateli do współdziałania z administracją. Brak zrozumienia informacji przez jej odbiorców nie może być argumentem za ograniczeniem działalności informacyjnej samorządowych organizacji publicznych.

Samorządowe organizacje publiczne stanowią integralną część systemu politycznego, podlegają jego wpływom, ale także odgrywają rolę w kształtowaniu biegu spraw publicznych, na co zwracają uwagę m.in. B.G. Peters, F. Anechiarico, J.B. Jacobs. W świetle powyższej konstatacji kluczowego znaczenia nabiera przeciwdziałanie asymetrii informacyjnej $\mathrm{w}$ relacjach pomiędzy organizacjami publicznymi i pozostałymi podmiotami. Postulat ten nawiązuje do teorii agencji, których przedstawicielami są M. Jensen i W. Meckling, ekonomicznego modelu biurokracji W. Niskanena, a także nowej ekonomii instytucjonalnej, zwłaszcza zidentyfikowanego przez O.E. Williamsona oportunizmu stron kontraktu, oraz teorii interesariuszy, którą w aspekcie zarządzania przedstawił E. Freeman w swojej pracy „Strategic Management. A Stakeholder Approach".

Przepływ informacji pomiędzy samorządowymi organizacjami publicznymi i interesariuszami powinien być symetryczny. Wyniki badań przeprowadzonych przez A.P. Wiatraka wykazały, iż ponad $60 \%$ badanych osób nie wiedziało, że samorządowa organizacja publiczna opracowała strategię rozwoju wspólnoty samorządowej ${ }^{10}$. Brak asymetrii w przepływie informacji wystąpił także pomiędzy administracją samorządową a organizacjami pozarządowymi. Ustalono, że choć samorządowe organizacje publiczne posiadały roczne programy współpracy międzysektorowej, to jednak w jednej szóstej badanych jednostek przygotowanie tych programów odbywało się bez udziału zainteresowanych interesariuszy (nie informowano interesariuszy o możliwości współuczestniczenia $\mathrm{w}$ przygotowaniu programów) ${ }^{11}$. Organizacje pozarządowe nie były traktowane jako równorzędny partner organizacji publicznych, lecz jako realizatorzy usług publicznych $^{12}$. Zagadnienie to powinno stanowić przedmiot ponowny pogłębionych badań.

Niezapewnienie przez samorządowe organizacje publiczne symetrii w przepływie informacji (w przypadkach, gdy dostęp interesariuszy do informacji nie jest ograniczony przepisami prawa, na przykład przepisami ustawy z dnia 5 sierpnia 2010r. o ochronie informacji niejawnych ${ }^{13}$ ) należy bowiem uznać za nieprawidłowość. Asymetria informacji katalizuje dysfunkcje organizacji, które w ekstremalnej formie, można traktować jako patologię organizacji, a zatem względnie trwałą niesprawność organizacji, która powoduje marnotrawstwo przekraczające granice społecznej tolerancji ${ }^{14}$. Przyczyn tej nieprawidłowości można upatrywać w zachowaniach dysfunkcjonalnych wymienionych przez M. Lizée, tj. postawie biurokratycznej, postawie negatywnej lub w dysfunkcjonalnym zachowaniu strategicznym.

10 A.P. Wiatrak, Strategie rozwoju gmin wiejskich, op.cit., s. 169-170.

11 W 15 z 93 objętych badaniem urzędów administracji samorządowej.

12 Z. Dobrowolski, Kontrola wspótpracy instytucji publicznych z organizacjami pozarzadowymi na przykładzie Najwyższej Izby Kontroli [w:] Rola organizacji pozarzadowych $w$ kształtowaniu społeczeństwa obywatelskiego. Doświadczenia i wyzwania, pod red. J. Babiak, W. Sługocki, Instytut Konsultantów Europejskich, Warszawa-Kalisz 2009, s. 78-99.

13 Dz.U. Nr 182, poz. 1228.

14 W. Kieżun, Sprawne zarządzanie organizacja, SGH, Warszawa 1997, s. 376. 
Wśród przyczyn niskiego zaangażowania społecznego mieszkańców gmin wiejskich należy wymienić także brak przekonania badanych osób, iż ich stanowisko jest brane pod uwagę przez władze samorządowe ${ }^{15}$. Zauważalne jest zatem ograniczone zaufanie lokalnej społeczności do działalności samorządowych organizacji publicznych. Tymczasem zaufanie stanowi fundament interakcji społecznych w organizacji. Jest źródłem kreowania kapitału społecznego, na co zwracają uwagę R. Putnam, R. Leonardi, R. Nanetti. Redukuje, według C. Handy, koszty transakcyjne i zachęca, jak zauważa P. Dasgupta, do uczestnictwa w transakcjach. Nadaje sens ludzkim działaniom i powoduje, że ludzie potrafią lepiej, skuteczniej współpracować ${ }^{16}$.

Przeprowadzone w 2012 r. badania CBOS wykazały, iż w życiu społecznym Polacy są raczej nieufni. Tylko niespełna jedna czwarta badanych $(23 \%)$ wychodzi z założenia, że większości ludzi można ufać, blisko trzy czwarte zaś (74\%) wyznaje zasadę zachowywania daleko idącej ostrożności w stosunkach $\mathrm{z}$ innymi. Polacy nie mają zbyt dobrego wyobrażenia o świecie otaczających ich instytucji i ufają im jedynie połowicznie. Odnotować należy, że choć, w porównaniu do 2002 r., w 2012 r. wzrosło zaufanie społeczne do władz lokalnych, odpowiednio z $43 \%$ do $58 \%$, to w przypadku urzędników administracji publicznej $\mathrm{w}$ dalszym ciągu odsetek respondentów deklarujących zaufanie jest niewielki, choć i tu odnotowano pewną poprawę. I tak, w 2002 r. $31 \%$ ogółu respondentów deklarowało zaufanie do urzędników, a w 2012 r. $45 \%{ }^{17}$. W świetle powyższych wyników badań stwierdzić należy, że zarówno planowanie i organizowanie działalności organizacji samorządowych (jednostek samorządu terytorialnego) a także motywowanie pracowników powinno być ukierunkowane na współpracę z interesariuszami, czemu służy kreowanie zaufania publicznego.

Zaufanie powinno być zatem zaliczane zarówno do warunków sine qua non działania, jak i rezultatów działalności. Poziom zaufania interesariuszy do organizacji samorządowej powinien stanowić o jej reputacji, która staje się wartością, umacnia pozycję organizacji w zmiennym otoczeniu ${ }^{18}$. Powinien być systematycznie mierzony i analizowany. Dzięki temu można podejmować stosowne działania sprzyjające umacnianiu zaufania. Tymczasem przegląd danych zawartych w losowo wybranych biuletynach informacji publicznej urzędów miast i gmin województwa lubuskiego (10\% ogółu gmin) ${ }^{19}$ wykazał, że nie badano poziomu zaufania społecznego do organizacji samorządowych. Celem dalszych pogłębionych badań powinno być ustalenie przyczyn braku pomiarów zaufania publicznego przez samorządowe organizacje publiczne (jednostki samorządu terytorialnego).

Zarządzanie w jednostkach samorządu terytorialnego, tak jak w pozostałych organizacjach publicznych, powinno służyć zapewnieniu wysokiego standardu realizacji potrzeb ludności i jednocześnie umacnianiu zasad demokracji obywatelskiej. Podstawą działania powinny być zatem takie zasady, jak:

15 A.P. Wiatrak, Strategie rozwoju gmin wiejskich, op.cit., s. 161.

16 W.M. Grudzewski, I.K. Hejduk, A. Sankowska, M. Wańtuchowicz, Zarzadzanie zaufaniem w organizacjach wirtualnych, Difin, Warszawa 2007, s. 31.

17 CBOS, Komunikat z badań. Zaufanie społeczne, Warszawa 2012.

18 J. Penz, Humanistyczne wartości zarządzania. W poszukiwaniu sensu menedżerskich działań, Difin, Warszawa 2010, s. 18.

19 Drezdenko, Gubin, Otyń, Międzyrzecz, Pszczew, Sulęcin, Zielona Góra, Żagań, Żary. 
- wspieranie rozwoju gospodarczego poprzez właściwe planowanie i implementację założeń prorozwojowych, w tym prowadzenie odpowiedniej strategii wobec przedsiębiorstw funkcjonujących na obszarze gminy oraz regionu, polityki zagospodarowania przestrzennego, zrównoważonej działalności inwestycyjnej, tj. takiej, która uwzględnia cele oświatowe, kulturalne lokalnej społeczności, a jednocześnie możliwości finansowe gminy i wymogi przedsiębiorców;

- ekonomizacja sfery samorządowej, a zatem uwzględnianie wymogów oszczędności, wydajności i skuteczności przy realizacji zadań;

- jakości świadczonych usług;

- rzetelności;

- przejrzystości;

- rozliczalności decydentów i urzędników;

- decentralizacji.

W procesie zarządzania należy zwrócić uwagę na: inspirowanie lokalnych lub regionalnych przedsięwzięć społecznych i gospodarczych i ich odpowiednie wykorzystywanie, utrzymywanie więzi ze społeczeństwem poprzez informowanie o działaniach oraz przez wspólne przedsięwzięcia na rzecz zaspokojenia zbiorowych potrzeb społeczeństwa, zapewnienie ładu przestrzennego, ochronę środowiska, sprawne prowadzenie gospodarki komunalnej ${ }^{20}$. Podzielam pogląd B. Kożuch, że sprawne zarządzanie współczesnymi organizacjami samorządowymi (jednostkami samorządu terytorialnego) ma innowacyjny charakter. Przy czym nie chodzi jedynie o wykorzystywanie nowoczesnych technologii $\mathrm{w}$ procesach świadczenia usług publicznych, na przykład e-administracji, która notabene jest ważna choć z punktu widzenia ekonomizacji sfery samorządowej, ale także o ukierunkowaną na innowacyjność współpracę z interesariuszami w takich obszarach, jak: wyznaczanie celów strategicznych, tworzenie warunków do współdziałania międzyorganizacyjnego i międzysektorowego, koordynacja polityk, programów, zadań z różnymi podmiotami, w tym nienależącymi do sektora publiczne$\mathrm{go}^{21}$.

\subsection{Zasada kontroli spolecznej}

Przedstawiony wyżej zbiór zasad należy uzupełnić o zasadę kontroli społecznej działalności samorządowych organizacji publicznych (jednostek samorządu terytorialnego). W warunkach niepewności spowodowanej złożonością procesu decyzyjnego wzrasta bowiem potrzeba weryfikacji sposobów gromadzenia, przetwarzania i przekazywania informacji w poszczególnych fazach procesu decyzyjnego. Weryfikacja, o której mowa wyżej jest niezbędna w przypadku partnerstwa publiczno-prywatnego, które oparte jest na współpracy pomiędzy dwoma sektorami, kierującymi się odmiennymi celami: sektorem publicznym odpowiedzialnym za realizację zadań o charakterze publicznym oraz sektorem prywatnym nastawionym na osiągnięcie zysku. Taka współpra-

20 B. Kożuch, Zarządzanie publiczne $w$ teorii $i$ w praktyce polskich organizacji, Wydawnictwo Placet, Warszawa 2004, s. 65-66.

21 B. Kożuch, Innowacyjność w zarządzaniu publicznym [w:] Nowe zarządzanie publiczne i public governance w Polsce i $w$ Europie, pod red. A. Bosiacki, H. Izdebski, A. Nelicki, I. Zachariasz, s. 42. 
ca generuje ryzyko, co zresztą dostrzega sam ustawodawca, tworząc przepisy ustawy z dnia 19 grudnia 2008 r. o partnerstwie publiczno-prywatnym ${ }^{22}$.

Kontrola i zaufanie są ze sobą związane. Istnieje niezamknięta dyskusja, czy są one substytucyjne względem siebie, suplementarne, komplementarne, czy też antagonistyczne. Ogólnie zaufanie i kontrola pomagają redukować postrzegane ryzyko do akceptowanego poziomu i czynić zachowania podmiotów bardziej przewidywalnymi ${ }^{23}$. Aby spełnić powyższy postulat, kontrolowanie musi być oparte na takich walorach, jak m.in.: rzetelność, obiektywizm, kompleksowość badań, pojmowana jako możliwość dogłębnego zbadania określonego wycinka rzeczywistości i dokonania jego oceny przy wykorzystaniu kryteriów: celowości, legalności, rzetelności, gospodarności.

Z uwagi na cel artykułu pomijam kwestie funkcji i zasad kontroli, odsyłając zainteresowanych do literatury poświęconej problematyce kontrolowania. Skupiam uwagę na możliwościach kontrolowania działalności organizacji samorządowych. Stwierdzam, iż skuteczność działalności nadzorczej i kontrolnej organu stanowiącego gminy jest ograniczona poprzez sieć wzajemnych powiązań, w tym politycznych. Ograniczone są także możliwości audytu wewnętrznego, który w ujęciu postulatywnym jest działalnością niezależną i obiektywną i której celem jest wspieranie kierownika organizacji publicznej w realizacji celów i zadań przez systematyczną ocenę kontroli zarządczej oraz czynności doradcze. W przypadku kontroli zarządczej, jednym z kluczowych jej narzędzi jest samoocena. Rzetelność samooceny jest uwarunkowana poziomem zaufania pracowników do przełożonych. Jest zatem trudna do zwymiarowania. Ocenie audytora podlega de facto spełnienie wymogów formalnych kontroli zarządczej, a to za mało, aby należycie wspierać kierownika w podejmowaniu trafnych decyzji, których powodzenie zależy przecież od sposobu ich wykonania przez pracowników. Skuteczność kontroli funkcjonalnej pracowników urzędu gminy, starostwa powiatowego lub urzędu marszałkowskiego jest ograniczona przez jej wycinkowość. Urzędnicy jedynie w pewnym zakresie biorą udział w procesie podejmowania decyzji.

Działalność samorządowych organizacji publicznych (jednostek samorządu terytorialnego) jest kontrolowana przez podmioty zewnętrzne. Kontrola sądowa skupia się wyłącznie na legalności podjętych decyzji. Z kolei wojewoda jest uprawniony do kontroli legalności, rzetelności i gospodarności działalności samorządowych organizacji publicznych, ale tylko w odniesieniu do realizacji przez te organizacje zadań z zakresu administracji rządowej. Funkcjonowanie samorządowych organizacji publicznych może być także kontrolowane przez inne organizacje publiczne, na przykład regionalne izby obrachunkowe (RIO), Najwyższą Izbę Kontroli (NIK). Zakres tych kontroli jest ograniczony np. organy te nie badają i oceniają celowości podjętych decyzji dotyczących realizacji zadań finansowanych ze środków własnych gminy. Ocenie nie podlega faza strukturyzacji problemu. Tymczasem w tej fazie procesu decyzyjnego określone podmioty mogą skutecznie wpływać na dokonywane przez decydenta wybory, kształt decyzji, dysponując większymi od innych podmiotów możliwościami finansowymi, eksperckimi, poparciem politycznym, czy zorganizowanym „szumem wokół sprawy”. Ponadto RIO może ocenić przedsięwzięcia organizatorskie finansowane ze środków wła-

22 tj. Dz. U. z 2009 r. Nr 19, poz. 100.

23 W.M. Grudzewski, I.K. Hejduk, A. Sankowska, M. Wańtuchowicz, Zarzadzanie zaufaniem w organizacjach wirtualnych, op.cit., s. 63-66. 
snych gminy tylko z punktu widzenia legalności i rzetelności. Tymczasem przedsięwzięcia legalne mogą być niegospodarne. Niemożność zweryfikowania badanej działalności poprzez pryzmat wydajności i oszczędności ogranicza możliwość kompleksowej oceny sposobu realizacji interesu publicznego przez organizacje samorządowe.

Kontrole działalności samorządowych organizacji publicznych (jednostek samorządu terytorialnego) przeprowadzane przez organy kontroli państwowej są nie tylko ograniczone kryteriami oceny kontrolowanej działalności. Kontrole te mają głównie charakter ex post. W przypadku kontroli ex post organy kontroli państwowej z opóźnieniem informują decydentów o wynikach diagnozy poziomu oddziaływania czynników mających zapewnić zgodność zachowań z oczekiwaniami. Tymczasem zadaniem kontroli jest regulowanie działania w celu dostosowania określonego systemu do oddziaływań płynących z otoczenia, przy czym skuteczność kontroli zależy nie tylko od stwierdzania odchyleń od wzorców lub ujawnienia, że przyjęto niewłaściwe założenia (wzorce), lecz także od szybkości reakcji na odstępstwa ${ }^{24}$.

W warunkach ograniczeń instytucjonalnej kontroli samorządowych organizacji publicznych (jednostek samorządu terytorialnego) znaczenia nabiera kontrola społeczna, która pozwala na zbadanie sposobu strukturyzacji problemów zarządzania. Sposób wspierania kontroli społecznej przez samorządowe organizacje publiczne świadczyć będzie o tym, czy zasada kreowania zaufania publicznego przez te organizacja pozostaje jedynie w sferze deklaracji, czy też jest faktycznie implementowana $\mathrm{w}$ ich codziennej działalności.

\section{PODSUMOWANIE}

W świetle przedstawionych $\mathrm{w}$ artykule rozważań stwierdzić należy, iż oprócz zidentyfikowanych w literaturze przedmiotu zasad zarządzania publicznego, które powinny być stosowane przez samorządowe organizacje publiczne (jednostki samorządu terytorialnego), takich jak m.in. ekonomizacji sfery samorządowej, decentralizacji, należy wymienić istotną z perspektywy partycypacyjnego zarządzania publicznego, zasadę kreowania zaufania publicznego.

Zaufanie powinno być zaliczane zarówno do warunków sine qua non działania, jak i rezultatów działalności. Poziom zaufania interesariuszy do organizacji samorządowej powinien być systematycznie mierzony i oceniany, gdyż stanowi o jej reputacji, która staje się wartością, umacnia pozycję organizacji w zmiennym otoczeniu.

Kreowaniu zaufania sprzyja nie tylko zapewnienie dostępności i rzetelności, ale także zrozumiałości informacji przekazywanej interesariuszom przez samorządowe organizacje publiczne. Ponadto $\mathrm{w}$ warunkach występujących ograniczeń w instytucjonalnej kontroli działalności samorządowych organizacji publicznych, znaczenia nabiera kontrola społeczna. Pozwala ona na zbadanie sposobu strukturyzacji problemu zarządzania.

Powyższe rozważania nie są próbą formułowania paradygmatu. Mają na celu wskazanie pożądanego kierunku działania samorządowych organizacji publicznych w warunkach społecznej partycypacji w realizacji zadań publicznych.

${ }^{24}$ B.R. Kuc, Kontrola w zarzqdzaniu przyszłościa, Wydawnictwo Menedżerskie PTM, Warszawa 2005, s. 16. 


\section{LITERATURA}

1. Bovaird T.,Löffler E., Understanding Public Management and Governance, [in:] Public Management and Governance, edited by Bovaird T., Löffler E., Routledge, London-New York 2003.

2. Bugdol M., Wymiary $i$ problemy zarzadzania organizacja oparta na zaufaniu, Wydawnictwo UJ, Kraków 2010.

3. Dobrowolski Z., Kontrola wspótpracy instytucji publicznych z organizacjami pozarządowymi na przykładzie Najwyższej Izby Kontroli, [w:] Rola organizacji pozarzadowych $w$ kształtowaniu społeczeństwa obywatelskiego. Doświadczenia $i$ wyzwania, pod red. Babiak J., Sługocki W., Instytut Konsultantów Europejskich, WarszawaKalisz 2009.

4. Grudzewski W.M., Hejduk I.K., Sankowska A., Wańtuchowicz M., Zarzadzanie zaufaniem w organizacjach wirtualnych, Difin, Warszawa 2007.

5. Hausner J., W kierunku rzadzenia interaktywnego, [w:] Nowe zarzadzanie publiczne $i$ public governance $w$ Polsce $i$ w Europie, pod red. Bosiacki A., Izdebski H., Nelicki A., Zachariasz I., Liber, Warszawa 2010.

6. Izdebski H., Od administracji publicznej do public governance, [w:] Zarzadzanie publiczne, pod red. Hausner J., Wydawnictwo Naukowe Scholar, Warszawa 2007.

7. Kieżun W., Sprawne zarzadzanie organizacja, SGH, Warszawa 1997.

8. Komunikat z badań. Zaufanie społeczne, CBOS, Warszawa 2012.

9. Koncepcja good governance - refleksje do dyskusji, Ministerstwo Rozwoju Regionalnego, Warszawa 2008 (maszynopis).

10. Kożuch B., Zarzadzanie publiczne $w$ teorii $i w$ praktyce polskich organizacji, Wydawnictwo Placet, Warszawa 2004.

11. Kożuch B., Innowacyjność w zarzadzaniu publicznym, [w:] Nowe zarzadzanie publiczne $i$ public governance $w$ Polsce $i w$ Europie, pod red. Bosiacki A., Izdebski H., Nelicki A., Zachariasz I., Liber, Warszawa 2010.

12. Kuc B.R., Kontrola $w$ zarządzaniu przyszłościa, Wydawnictwo Menedżerskie PTM, Warszawa 2005.

13. Managing Development. The Governance Dimension, World Bank, Washington D.C. 1991 (maszynopis).

14. Penz J., Humanistyczne wartości zarządzania. W poszukiwaniu sensu menedżerskich działań, Difin, Warszawa 2010.

15. Wiatrak A.P., Strategie rozwoju gmin wiejskich, Instytut Rozwoju Wsi i Rolnictwa, PAN, Warszawa 2011.

\section{MAGAGEMET IN LOCAL PUBLIC ORGANIZATIONS IN THE CONDITIONS OF SOCIAL PARTICIPATION IN IMPLEMENTATION OF PUBLIC TASKS}

\section{Summary}

Nowadays public tasks are implemented not only by public organizations but also by nongovernmental actors, including public-private partnerships. Under such conditions, the proper 
execution of tasks by local public organizations, which includes among other things gathering resources, requires cooperation and coordination of different activities with other stakeholders. It should enable the achievement of organizational needs at the right time and the better achievement of objectives. The result of the management of local public organizations should ensure a high standard of public tasks performed in the public interest and at the same time enhance the principles of democracy.

Based on literature studies and research work, this article is to determine the principles of public management in the conditions of social participation in the implementation of public tasks. The author claims that creating public trust is crucial from the perspective of participatory governance. It can be achieved not only by ensuring the availability and reliability, but also the clarity of information. Supporting the development of social control, public organizations also create public trust.

Trust should be included in both the sine qua non condition of action, as well as the results of operations. The level of stakeholder confidence to the local public organization should be considered as an assessment of organizational reputation, which becomes its value, and strengthens the position of the organization in its changing environment.

Keywords: local government, participatory public management, trust management, social control

\section{NOTA BIOGRAFICZNA}

dr hab. Zbysław DOBROWOLSKI, prof. PWSZ - jest członkiem Rady Instytutu Spraw Publicznych Wydziału Zarządzania i Komunikacji Społecznej Uniwersytetu Jagiellońskiego w Krakowie oraz Instytutu Prawa i Administracji PWSZ w Sulechowie. Redaktor prestiżowego International Journal of Government Financial Management, USA. Autor kilkudziesięciu publikacji naukowych i zawodowych poświęconych W większości problematyce zarządzania w sektorze publicznym. 